Meta

Journal des traducteurs

Translators' Journal

\title{
Néologismes publicitaires
}

\section{André Clas}

Volume 17, numéro 1, mars 1972

L’adaptation publicitaire

URI : https://id.erudit.org/iderudit/002317ar

DOI : https://doi.org/10.7202/002317ar

Aller au sommaire du numéro

Éditeur(s)

Les Presses de l'Université de Montréal

ISSN

0026-0452 (imprimé)

1492-1421 (numérique)

Découvrir la revue

Citer ce document

Clas, A. (1972). Néologismes publicitaires. Meta, 17(1), 71-71.

https://doi.org/10.7202/002317ar

Ce document est protégé par la loi sur le droit d'auteur. L'utilisation des services d'Érudit (y compris la reproduction) est assujettie à sa politique d'utilisation que vous pouvez consulter en ligne.

https://apropos.erudit.org/fr/usagers/politique-dutilisation/
Cet article est diffusé et préservé par Érudit.

Érudit est un consortium interuniversitaire sans but lucratif composé de l'Université de Montréal, l'Université Laval et l'Université du Québec à Montréal. Il a pour mission la promotion et la valorisation de la recherche. https://www.erudit.org/fr/ 


\section{Néologismes publicitaires}

La publicité est grande consommatrice de mots. Chaque jour elle en invente de nouveaux et les diffuse aux quatre vents.

Les chercheurs de l'Observatoire du français contemporain de l'Université de Montréal ont relevé, l'an dernier, dans les revues et journaux français plus de 15000 mots qui ne figurent dans aucun dictionnaire.

La liste des mots «nouveaux » que nous présentons ici n'est pas exhaustive, elle n'a d'autre but que de livrer à la réflexion de nos lecteurs un échantillon de néologismes apportés par le «vent publicitaire» et de montrer l'importance des mass media dans l'enrichissement et la transformation du lexique.

ANDré Cras 